\title{
MECHANICAL PROPERTIES OF HONEYCOMB STRUCTURED ZR-BASED BULK METALLIC GLASS SPECIMENS FABRICATED BY LASER POWDER BED FUSION
}

\author{
J. Wegner ${ }^{1 *}$, M. Frey ${ }^{2}$, P. Stiglmair ${ }^{2}$, S. Kleszczynski ${ }^{1}$, G. Witt ${ }^{1} \&$ R. Busch ${ }^{2}$
}

\section{ARTICLE INFO}

\begin{tabular}{|c|c|c|}
\hline \multicolumn{3}{|c|}{$\begin{array}{l}\text { Presented at the } 20^{\text {th }} \text { annual } \\
\text { international conference of the Rapid } \\
\text { Product Development Association of } \\
\text { South Africa (RAPDASA), held from } 6-8 \\
\text { November } 2019 \text { in Bloemfontein, South } \\
\text { Africa }\end{array}$} \\
\hline & lable online & 15 Nov 2019 \\
\hline \multicolumn{3}{|c|}{ Contact details } \\
\hline \multicolumn{3}{|c|}{ Author affiliations } \\
\hline & $\begin{array}{l}\text { Department } \\
\text { Technology, } \\
\text { Essen, Germ }\end{array}$ & $\begin{array}{l}\text { facturing } \\
\text { ity Duisburg- }\end{array}$ \\
\hline & $\begin{array}{l}\text { Chair of Met } \\
\text { Saarland Un }\end{array}$ & $\begin{array}{l}\text { erials, } \\
\text { Germany }\end{array}$ \\
\hline
\end{tabular}

DOI

http://dx.doi.org/10.7166/30-3-2265
Laser powder bed fusion of bulk metallic glasses offers great potential to overcome the existing restrictions of the geometrical size and complexity of bulk metallic glasses in conventional manufacturing routes due to high cooling rates during laser powder bed fusion. Bulk metallic glasses exhibit extraordinary strength, paired with high elasticity. Yet insights into additive manufactured bulk metallic glasses, especially of complex structures, are limited. The present article investigates the mechanical behaviour of $\mathrm{Zr}$ based bulk metallic glasses, fabricated into honeycomb structures through laser powder bed fusion, by performing three-point bending tests. The results reveal a significant increase in specific strength, quasi-plasticity, and high elastic elongation. These structures thus offer great potential for light-weight applications and compliant mechanisms.

\section{OPSOMMING}

Laser poeierbedfusie van grootmaat glasagtige metale bied die potensiaal om die bestaande beperkings (verwant aan geometriese grootte en kompleksiteit) van glasagtige metale in konvensionele vervaardigingstegnieke te oorkom. Dit is as gevolg van die hoë afkoeltempo's tydens laser poeierbedfusie. Grootmaat glasagtige metale bied buitengewone sterkte saam met hoë elastisiteit. Insig in toevoegingsvervaardiging vir glasagtige metale is beperk, veral in die geval van ingewikkelde vorms. Hierdie artikel ondersoek die meganiese eienskappe van $\mathrm{Zr}$-gebaseerde glasagtige metale (wat in heuningkoekvorms vervaardig is deur laser poeierbedfusie) deur middel van drie-punt buigtoetse. Die resultate toon 'n noemenswaardige toename in spesifieke sterkte, quasi-plastisiteit, en hoë vlakke van elastiese verlenging. Die vorms bied hou dus potensiaal vir ligte toepassings en elastiese meganismes in.

\section{INTRODUCTION}

Exceptional mechanical and technological properties make bulk metallic glasses (BMGs) promising materials for numerous technical applications. Despite their desirable characteristics, their application is presently limited due to the challenging manufacturing process. The first metallic glass with the atomic composition $\mathrm{Au}_{75} \mathrm{Si}_{25}$ was synthesised by Duwez, Willens and Klement [1] in 1960 using rapid melt quenching. Thanks to the high cooling rate of about $10^{6} \mathrm{~K} / \mathrm{s}$, crystallisation was avoided and the amorphous, long-range order lacking atomic structure of the liquid state was frozen in (vitrification). The need for such high cooling rates limited the size of the amorphous metallic samples to several microns. Since then, extensive alloy development has led to morecomponent alloy systems with distinctly higher glass-forming ability (GFA) that can be vitrified at distinctly slower cooling rates. This has resulted in the creation of a new material class, the socalled bulk metallic glasses, which can form amorphous samples with thicknesses of $1 \mathrm{~mm}$ or more via classical casting routes [2]. High strength (1-6 GPa) and hardness, combined with - for metallic materials - exceptional elastic limits of about $2.0 \%$ make BMGs attractive for numerous industrial 
applications [3]. However, the critical cooling rates to achieve the amorphous state are still in the order of roughly $100 \mathrm{~K} / \mathrm{s}$ for most application-attractive alloys, restricting the size and complexity of parts produced by conventional casting processes [4]. An auspicious processing route to overcome these restrictions is additive manufacturing through laser powder bed fusion (LPBF). Due to highly dynamic laser scanning and small melt pools, typical cooling rates are up to $10^{6} \mathrm{~K} / \mathrm{s}$ [2] and are therefore suitable for amorphous solidification of BMGs [5, 6]. Furthermore, the layer-wise built strategy and selective melting allow for local cooling rates largely to be decoupled from the actual part dimensions. Initially published by Pauly et al. [7], investigating a Fe-based alloy, LPBF of various $\mathrm{Zr}-$, Fe-, Al-, and Ti-based alloys have been reported in recent years [8-15]. One can conclude that adequate parameter selection may lead to sufficient cooling rates and hence amorphous solidification. Nevertheless, cracking, partial crystallisation in the heat-affected zone (HAZ), and porosity are current challenges. In this context, the applied energy input represents a crucial balancing factor between crystallisation on the one hand and porosity on the other [11]. Since both are equally undesired and detrimental to mechanical performance, only small parameterbandwidths are suitable to achieve a low level of defects. Besides improving manufacturable size, as is shown in, among others, by Mahbooba et al. in [15] and the Heraeus GmbH in [16], further challenges and possibilities are still present. For instance, the mechanical properties of additively manufactured BMGs have not reached their cast reference yet. Although elasticity, strength, and hardness are comparable, plasticity in flexural bending-tests is still rarely attained. The observed embrittlement during the LPBF-process might be attributed to stress concentrations located in remaining porosity, elevated oxygen content, or relaxation, but this has not yet been conclusively proven $[14,17]$. It is reported that plasticity can be improved through geometrical design in cellular or porous structures for conventional manufactured BMGs [18-20], making such structures attractive for additive manufactured BMGs, due not only to their superior mechanical properties, but also to their lightweight potential. Owing to the demanding control process, the influence of geometrical complexity is rarely considered in laser powder bed fused BMGs. Since the increasing boundary surface between powder bed and exposed area decreases the maximal heat dissipation due to the significantly lower heat conductivity of the powder-bed [21], the risk of crystallisation grows. For instance, Yang et al. reported in [22] the presence of crystalline fractions of 10-26\%, depending on the geometrical shape of Zr-based BMG-grid structures. While the requirements for the GFA, design, and process rise, complex geometrical BMG structures provide high potential for tailored mechanical properties, compliant mechanisms [23], and AM-specific added values [24]. The present contribution intends to evaluate the structural influence on the resulting mechanical properties of various honeycomb structures for a Zr-based BMG-alloy.

\section{MATERIALS AND EXPERIMENTAL PROCEDURE}

\subsection{Materials and process}

Two gas-atomised powder derivates of the commercially available alloy AMZ4 with a composition of $\mathrm{Zr}_{59.3} \mathrm{Cu}_{28.8} \mathrm{Al}_{10.4} \mathrm{Nb}_{1.5}$ (in at\%) were provided by Heraeus $\mathrm{GmbH}$ [25]. While one derivate, further referred to as $\mathrm{P} 1$, was atomised using commercial-grade materials, the second derivate (P2) contained laboratory-grade starting materials. The derivates differed slightly in their particle size distribution, showing an average particle size $x_{50}$ of $23.65 \mu \mathrm{m}$ (P1) and $37.80 \mu \mathrm{m}$ (P2), optically measured with a Camsizer X2 (Retsch Technology $\mathrm{GmbH}$ ). Closer observations using optical microscopy (BX51M Olympus $\mathrm{GmbH}$ ) revealed an increased number of elongated irregular particles for both batches, as illustrated in Figure 1. The morphologic abnormalities can be attributed to the relatively high viscosities of BMG melts compared with crystalline metals. The viscous behaviour leads to insufficient timespans for a spherical formation during atomisation [4, 26].

The powders were manufactured into honeycomb beams with five different structures, with their respective bulk samples as reference, in a sample size of four each, as shown in Figures 2 and 3. The outer dimensions were $2.8 \times 1.9 \times 25.2 \mathrm{~mm}$ (thickness $\mathrm{x}$ height $\mathrm{x}$ length). The nominal cell height $h$ in their structures varied (Figure 2) between $0.12 \mathrm{~mm}$ and $0.8 \mathrm{~mm}$, with a constant wall thickness of $0.1 \mathrm{~mm}$, and a surrounding frame of $0.5 \mathrm{~mm}$. All processes were executed in an argon atmosphere using an industrial M100 LPBF-system (eos $\mathrm{GmbH}$ ) with a residual oxygen level below $500 \pm 200 \mathrm{ppm}$ measured by the integrated oxygen sensor. Process parameters were set according to previous work as published by Wegner et al. in [27]. In order to counteract the reduced heat dissipation within the thin-walled structures, the energy input was slightly reduced to a resulting volume energy density of $25 \mathrm{~J} / \mathrm{mm}^{3}$. Exposure was set to a rotating hatch strategy with skywriting to avoid acceleration effects in the scan paths. 

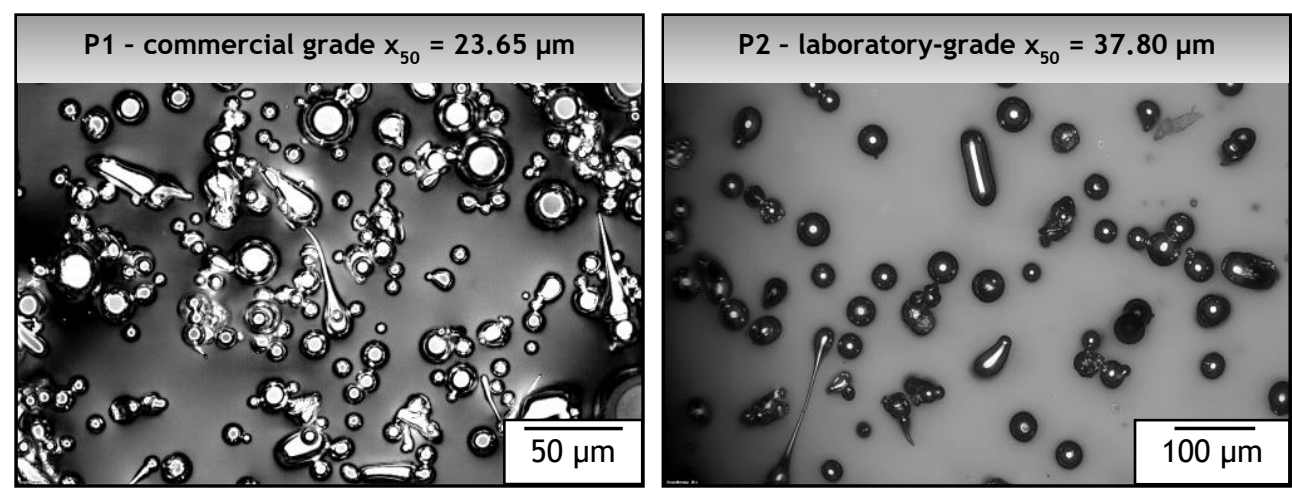

Figure 1: Light microscopy of the commercial grade batch P1 (left) with an average particle size $x_{50}=23.65 \mu \mathrm{m}$, and the laboratory-grade material P2 with $x_{50}=37.80 \mu \mathrm{m}$ (right).

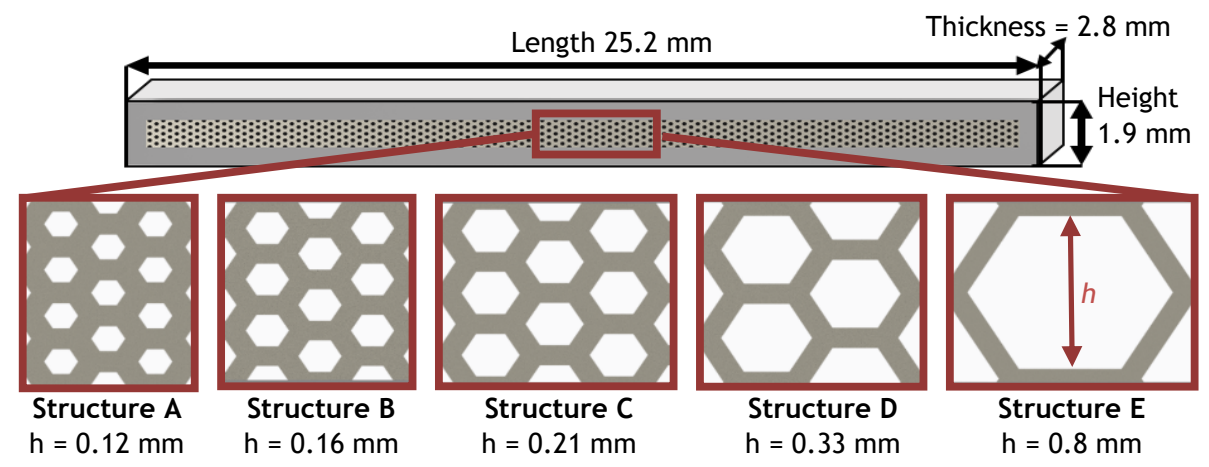

Figure 2: Overview of sample dimensions and honeycomb structures.

\subsection{Mechanical testing and analytics}

Mechanical testing was performed using a three-point flexural bending method. The samples were loaded perpendicular to the honeycomb cavities, as shown in the left half of Figure 3. To achieve a well-defined sample geometry, the external contour was sanded and polished. Using the measurement signals loading force $F$ and midpoint displacement $D$, stress $\sigma_{f}$ and strain $\varepsilon_{f}$ at the outer surface at midpoint were calculated according to:

$$
\begin{gathered}
\sigma_{f}=\frac{F L h}{8} \frac{1}{I} \\
\varepsilon_{f}=\frac{6 D h}{L^{2}}
\end{gathered}
$$

The distance between the supports $L$ during bending was $20 \mathrm{~mm}$, applying deformation with a velocity of $0.2 \mathrm{~mm} / \mathrm{min}$. Beam height $h$ was measured after polishing and $I$, as the second moment of inertia, was calculated by the CAD-program Creo Parametric 5.0. Neglecting shape and dimensional deviations in the honeycomb structures itself, the nominal sample geometry was therefore digitally matched for each sample according to its outer dimensions after polishing, in order to approximate $I$ along the cross-section, as illustrated in Figure 3. Since the point of crack initiation is unknown and varies over the sample size, the resulting stress of each sample was calculated according to (1), based on the measured force and geometry, with its own averaged moment of inertia. Since the averaged moment of inertia of a honeycomb structure is generally lower than for a bulk geometry, calculated stresses are increased. 

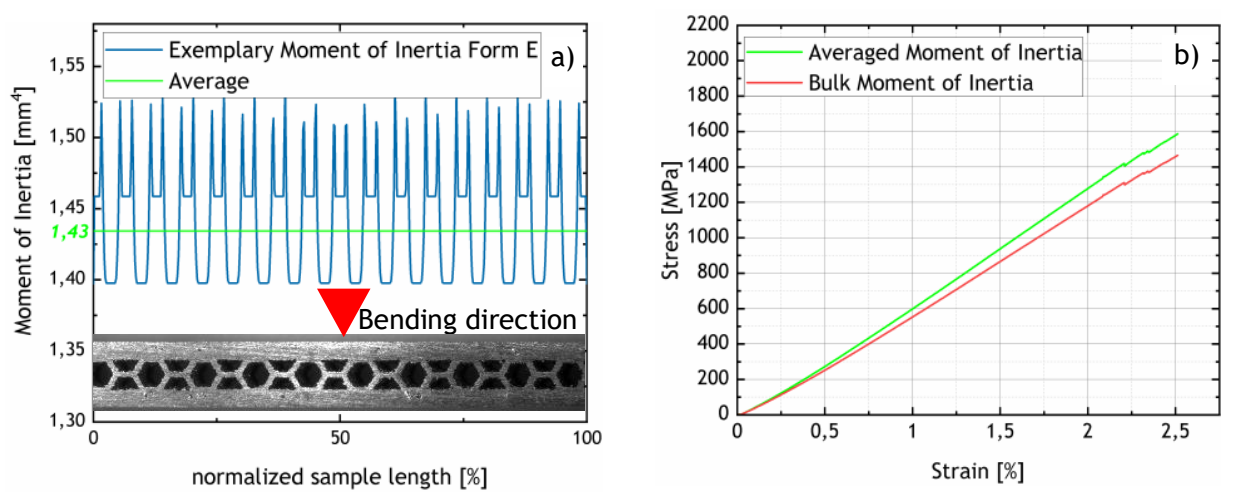

Figure 3: Left: Illustration of the moment of inertia along the sample length of honeycomb Structure E; Right: Exemplary comparison of the adapted stress-strain curve according to the averaged moment of inertia (green), and assuming bulk sample geometry (red) for structure $E$ (see online version for colour)

After mechanical testing, one half of each sample was further prepared for optical density measurements. The samples were embedded in epoxy, followed by grinding and polishing down to $1 \mu \mathrm{m}$ diamond suspension. The optical analysis was performed using the Stream Essentials software from Olympus $\mathrm{GmbH}$. In the evaluation of the images, it was possible to distinguish between intrinsic porosity $\rho_{\text {int }}$ and relative density $\rho_{\text {rel }}$. In this context, 'intrinsic porosity' refers to the residual porosity after the build process in the areas that were designed to be solid, such as the surrounding frame and the honey-comb walls itself. The relative density serves to describe the fraction of solid material compared with the theoretical full-body geometry. The remaining halves of the samples were analysed using differential scanning calorimetry (DSC) and X-ray diffraction (XRD) measurements to verify the amorphous state. DSC temperature scans from $50^{\circ} \mathrm{C}$ up to $580^{\circ} \mathrm{C}$ with a rate of $60 \mathrm{~K} / \mathrm{min}$ were performed under argon atmosphere by using a Perkin Elmer Diamond DSC. XRD was carried out using an X'Pert Pro MPD (Panalytical) diffractometer in an angular range (2 $\theta)$ of $20^{\circ}$ to $80^{\circ}$. The $\mathrm{K}_{\mathrm{a}}$ radiation of copper with a wavelength of $1.5406 \AA$ was used.

\section{$3 \quad$ RESULTS AND DISCUSSION}

The created scan tracks appear continuous and viscously solidified without welding track scales, as shown in Figure 4, which is typical for crystalline metals. Due to the limited resolution of the $40 \mu \mathrm{m}$ beam-diameter and melt pool overflow, the geometrical accuracy decreases with reduced cell-size, leading to irregular and mainly fused honeycomb-cells for structure type A (pictured in Figure 4 and Figure 6).
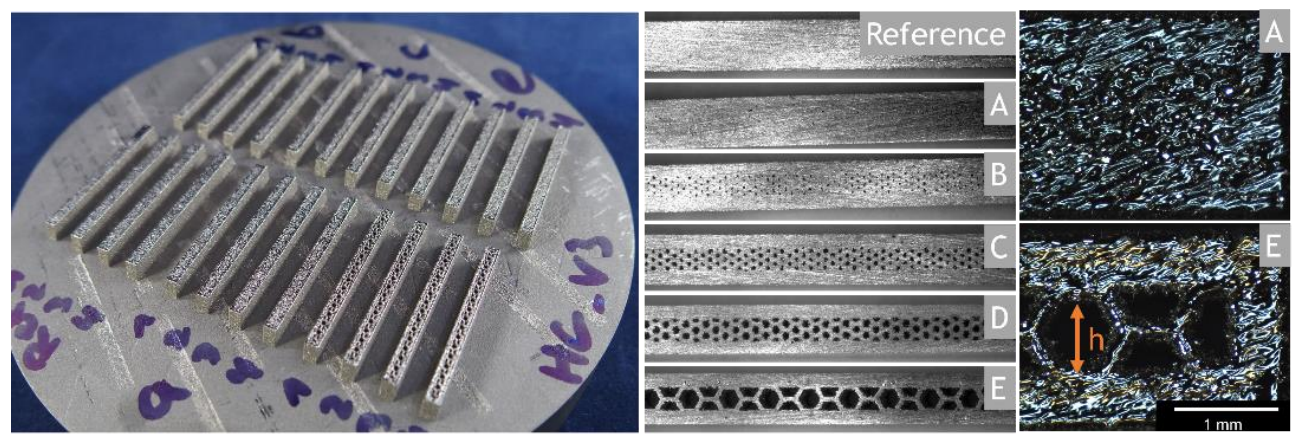

Figure 4: Left: Sample arrangement on the built plate. Right: Macroscopic images of the ground beams before bending, and with welding track illustration. Nominal honeycomb cell heights in mm: $h_{A}=0.12 ; h_{B}=0.16 ; h_{C}=0.21 ; h_{D}=0.33 ; h_{E}=0.8$ (see online version for colour)

While most of the samples for both materials were processed successfully, structure type B for powder derivate P2 suffered from short feed-induced elevations during the process. Due to significant defects after removal from the substrate, the sample size was reduced to two. The results 
of the mechanical testing for both powder derivates are displayed in Figures 5 a) and $5 \mathrm{~b}$ ). The stress-strain curves for each sample series of the respective geometry and powder derivate were averaged and plotted by applying the mean section moments of inertia, as described in Section 2 . The results for P1-samples show generally increased flexural bending strength for cell-heights up to $0.33 \mathrm{~mm}$ (form D), compared with the bulk reference samples. All samples exhibited brittle fracture and comparable E-moduli. The highest strength emerged for samples of the honeycomb structure A. In contrast, the coarser honeycomb structures inhere lowered E-moduli and strength, accompanied with higher strains at fracture. In contrast to the other samples, the coarse structures $E$ show quasiplastic failures due to stepwise cracking, noticeable in Figure 3 b) by the sharp stress drop at strains over $2.0 \%$. The laboratory-grade samples (P2) show generally higher flexural strengths, while the structural influence follows the same trend for structures $A$ and $B$.
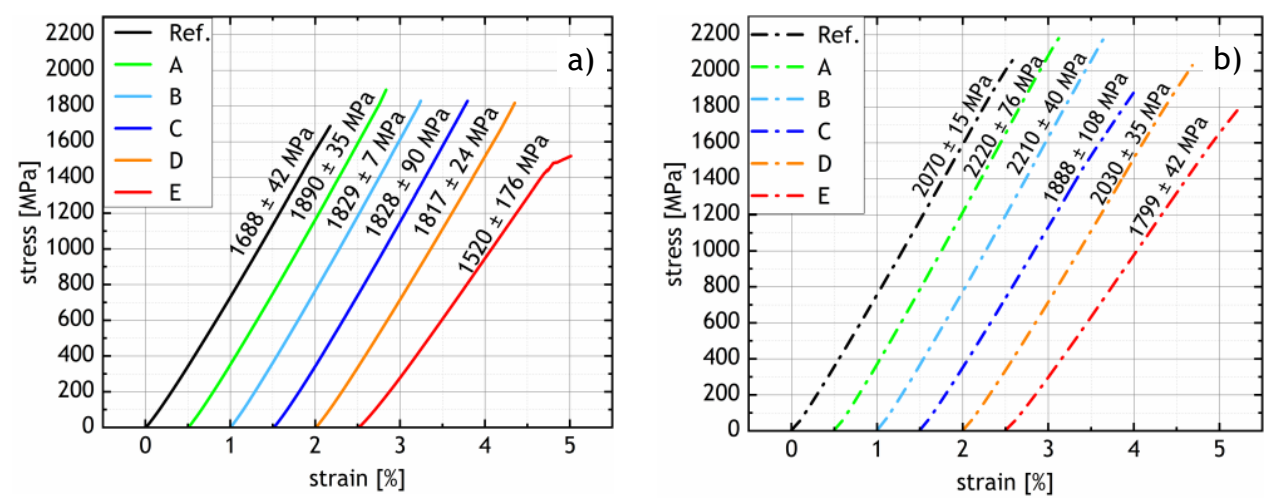

Figure 5: Averaged stress-strain curves with averaged moments of inertia for a) commercial grade powder $\mathbf{P 1}$, and $\mathrm{b}$ ) laboratory-grade $\mathbf{P} 2$. Curves are shifted along the $\mathrm{x}$-axis for visualisation purposes with their maximum flexural stress labelled (see online version for colour)

The better performance of the P2 samples can be explained by the smaller amount of oxygen contamination in the laboratory grade material, leading to decreased oxygen embrittlement $[14,17]$. The sample series $C$ of P2 inheres significant deviation in its strength and relative density (Figure 6), which is most likely attributed to the local process discontinuities, as described above. Contrary to $\mathrm{P} 1$, neither an increased strength for structure D nor a significant weakening is present. It is noteworthy that both powder derivates achieve strengthening with small honeycomb diameters in terms of the stress-strain curves. The structural advantages of the honeycomb structures become even clearer considering their specific strength. Figure 6 summarises the results of the optical density measurements, showing a variation in relative density between $99.15 \%$ in structure $A$ and $68.21 \%$ for the largest structure E. The specific strength (Figure 6) was calculated by the product of strength and relative density divided by the absolute density of AMZ4 $\left(6.616 \mathrm{~g} / \mathrm{cm}^{3}\right.$ measured on conventionally cast samples via the Archimedes principle). It increases with structure size, leading to the highest value in structure $E$, with $331 \pm 17 \mathrm{MPa} /\left(\mathrm{g} / \mathrm{cm}^{3}\right)$ for $\mathrm{P} 1$ and $374 \pm 17 \mathrm{MPa} /\left(\mathrm{g} / \mathrm{cm}^{3}\right)$ for $\mathrm{P} 2$, corresponding to an increase of $25.7 \%$ and $17.4 \%$ relative to the bulk reference.

The results are particularly remarkable because the internal structures in A are largely fused. Therefore, they form irregular porosities rather than honeycomb cells, as shown in Figures 4 and 7 . While the intrinsic porosity $\rho_{\text {int }}$ is below $1.0 \%$ for all samples, it appears that the artificially reduced density, even if resulting in irregularly shaped pores, does not provoke premature failure. On the contrary, irregular porosities up to $1.4 \%$ (like structure A), and periodic porosities up to $10.4 \%$ (as for structure $\mathrm{C}$ ) still appear to enhance the flexural strength. It must be mentioned that the averaged moment of inertia as applied in Figure 5 lacks accuracy for the fused structures, as in A, and neglects geometrical deviations that are especially present in B and C. Nevertheless, even a computational underestimation of the structures, due to the assumption of solid bodies, follows the trend of strengthening, as pointed out in Figure 7. It can be seen, although it is less pronounced, that the flexural strength of the reference is still lower than A, B, and C of P1, even without an adapted moment of inertia or respective weight adjustment. The effect diminishes for structure $C$ within the standard deviation, probably due to the significant deviation between the sample geometry and the assumed solid body. 

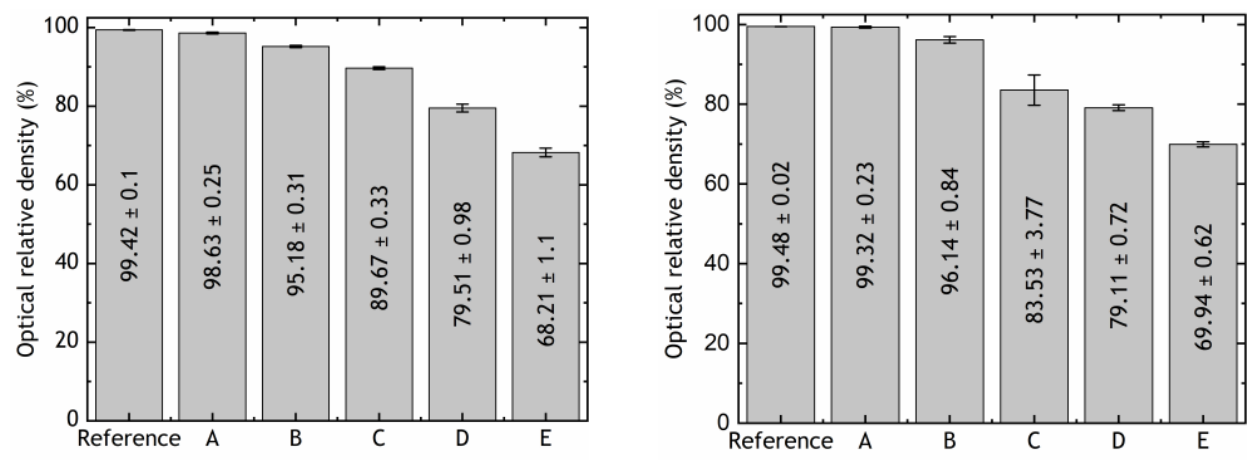

Honeycomb structures - Batch P1
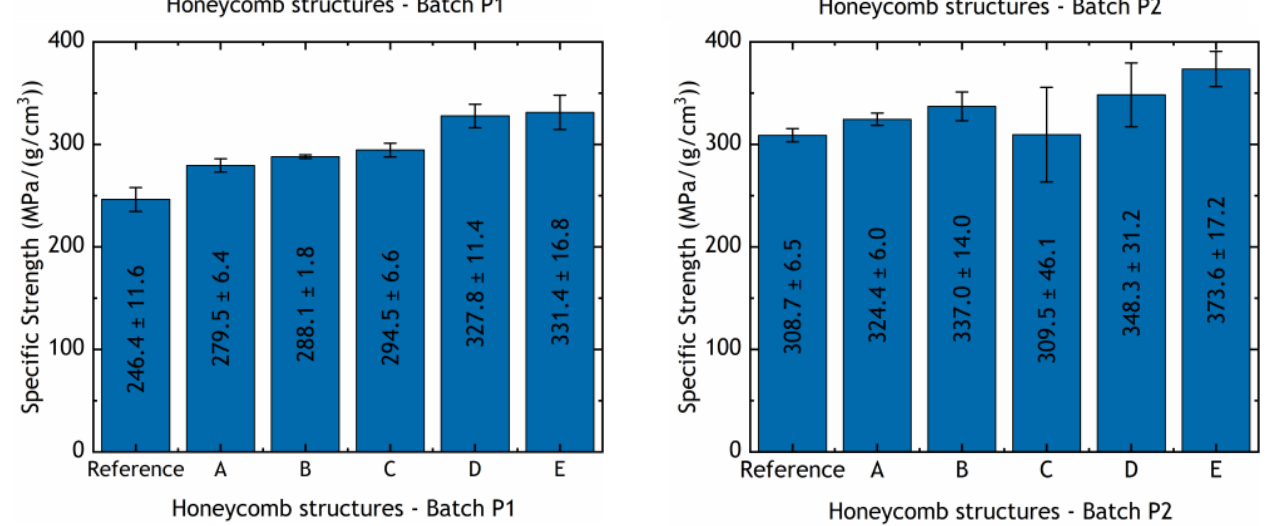

Figure 6: Optically measured relative density (top), and specific strength in relation to the resulting absolute density for both powder derivates (bottom).

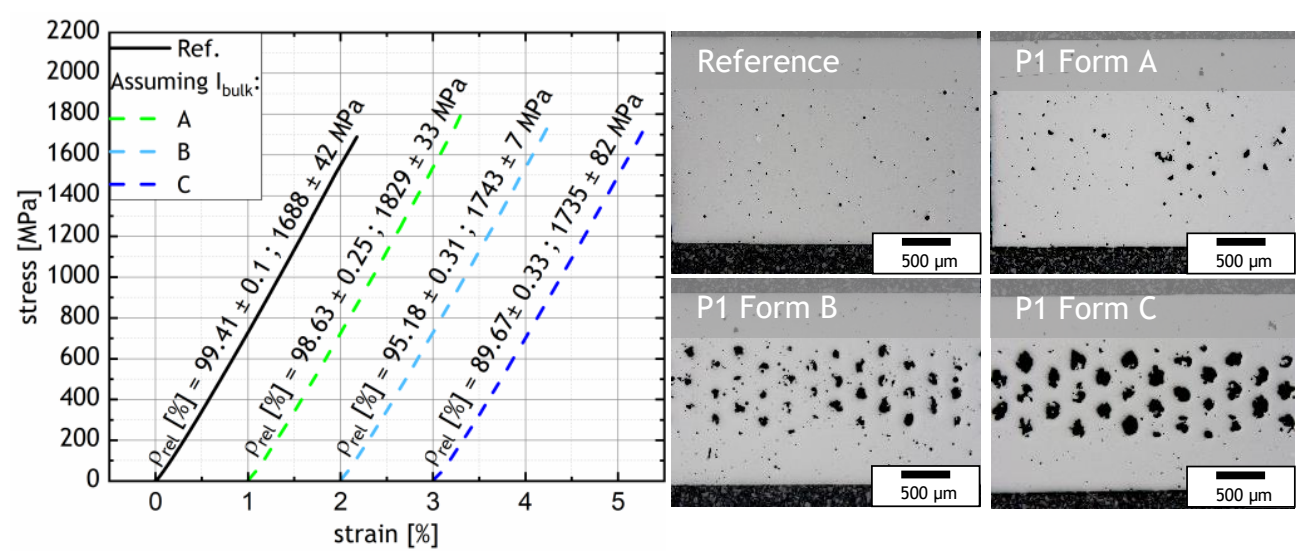

Figure 7: Stress-strain curves calculated assuming bulk moments of inertia for P1. Comparing the reference sample with spherical porosities, structure $A$ with irregular pores, and structures $B$ and $C$ with periodic porosities (see online version for colour)

The varying conditions lead to an increased exposure time per part and layer from $0.79 \mathrm{~s}$ for bulk reference samples to $2.25 \mathrm{~s}$ for structure $A$. Therefore, slightly changed thermal conditions for the reduced accumulated temperatures in the HAZ could change the thermophysical properties and, therefore, the mechanical behaviour. Yet DSC and XRD analysis after bending did not show any sign of crystallisation within the detection limits. The DSC scan measurements (Figure 8) show the typical appearance of amorphous AMZ4: a relatively stable heat flow in the glassy state up to about $400^{\circ} \mathrm{C}$, followed by an endothermal rise in the heat flow caused by the glass transition, at which the glass devitrifies into the supercooled liquid state. At further increased temperatures, between roughly $470^{\circ} \mathrm{C}$ and $550^{\circ} \mathrm{C}$, crystallisation occurs and is indicated by a massive exothermal event. The enthalpy of crystallisation $\Delta H_{x}$ is obtained by integrating this signal. All samples show similar $\Delta H_{x}$ values, which are in the order of those for fully amorphous casted AMZ4 [28], substantiating the absence of crystalline precipitations within the detection limit. Furthermore, the diffractograms of 
the powder material (P1 and P2) and the manufactured LPBF-samples shown in Figure 9 reveal the typical broad halo of amorphous solids without any sharp reflexes, which would indicate crystalline structures.
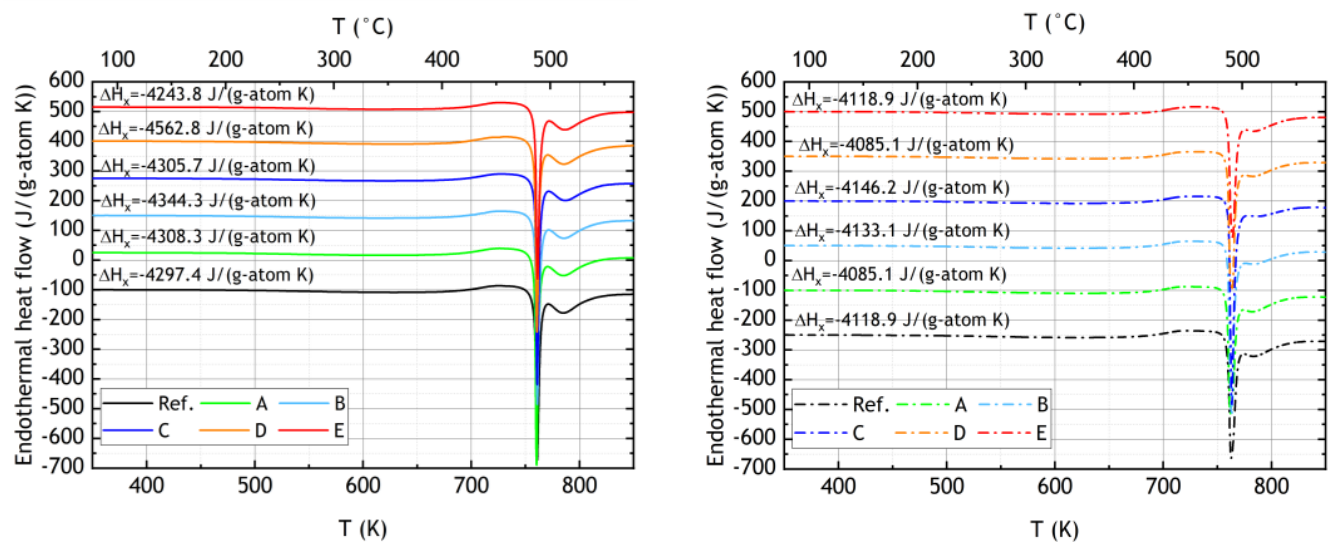

Figure 8: DSC-scans with a rate of $60 \mathrm{~K} / \mathrm{min}$ for P1 (left) and P2 (right) (see online version for colour)

The results conclusively indicate a fully amorphous microstructure of the material before and after processing. Consequently, the changes in mechanical behaviour cannot be attributed to partial crystallisation, at least within the detection limits, although nano-crystallisation below the detection limits may not be excluded conclusively.
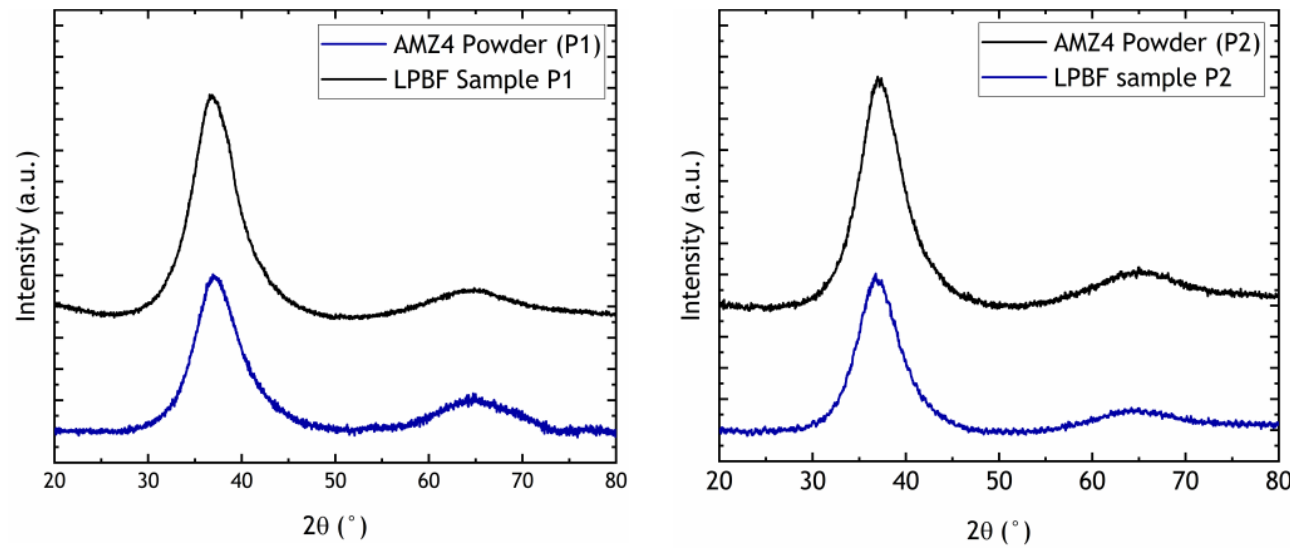

Figure 9: XRD-measurement of powder and exemplary samples for P1 (left) and P2 (right) (see online version for colour)

A more probable cause is an alteration in the deformation mechanisms and stress field. Besides the varied residual stress states because of shortened scan vectors, as discussed above, the artificial porosity may lead to variations in shear band forming due to the geometrical influence of the artificial defects. Finally, further investigations must be executed conclusively to explain the observed strengthening. For example, FEM simulations might help to understand the rather complex stress and deformation processes in the honeycomb structures.

\section{CONCLUSION}

The present contribution was employed to evaluate the structural influences on the mechanical behaviour of additively manufactured Zr-Cu-Al-Nb (AMZ4) BMG through LPBF. The influence of various honeycomb structures on the mechanical behaviour of two different powder derivates was compared. It can be concluded that, despite the reduced heat dissipation within the thin-walled structures, no detectable crystallisation of the samples was observed within the analysed range. The results reveal a significant increase in specific strength, with increasing honeycomb size up to $375 \mathrm{MPa} /\left(\mathrm{g} / \mathrm{cm}^{3}\right)$, 
with generally superior performance of the high purity derivate P2. While honeycomb structures up to $0.33 \mathrm{~mm}$ cell-height possess equivalent $\mathrm{E}$-moduli and increased absolute flexural stress compared with their reference, the tallest cell-height of $0.8 \mathrm{~mm}$ shows lowered $\mathrm{E}$-moduli and absolute strength; and yet quasi-plasticity through stepwise cracking was achieved. It appears that, even if the geometrical resolution of the LPBF-system is reached, resulting in irregular structural porosity rather than honeycombs, the flexural strength exceeds the solid reference. The effect could not be explained by thermophysical and microstructural analysis in terms of DSC and XRD. Therefore, it can be suggested that either small-scale thermophysical effects beneath the detection limits of the applied measuring technique or a change in deformation behaviour due to varied residual stress and shear band formation are present. Further investigations are necessary conclusively to understand the observed behaviour. For this purpose, especially the influence of the residual stress, exposure cycle time as much as pore size and distribution should be analysed in future. No critical weakening was caused by the elevated surface roughness or structural notches within the honeycombs. Therefore, the applicability of lattice structured BMGs fabricated through LPBF for structural elements seems suitable and promising for future applications. The observed quasi-plasticity of the coarse honeycomb structures has the potential to overcome critical crack propagation, possibly leading to higher failure tolerance through advanced structure design. The high specific strength, combined with elastic elongation of more than $2.0 \%$, makes Zr-based BMGs highly attractive for high stressed structural lightweight applications and compliant mechanisms.

\section{ACKNOWLEDGMENTS}

The authors would like to thank Prof. Winterer from the Chair of Nanoprozess Technologie and Prof. Fischer from the Chair of Materials Engineering at the University of Duisburg-Essen for their extensive support in carrying out XRD measurements and metallography.

The IGF project $19927 \mathrm{~N}$ of the Forschungsvereiniung Feinmechanik, Optik und Medizintechnik e.V. (Research Association for Precision Mechanics, Optics and Medical Technology) (FOM), Werderscher Markt 15, 10117 Berlin, was funded by the German Federal Ministry of Economics and Energy within the framework of the AiF's Programme for the Promotion of Industrial Community Research (IGF) on the basis of a resolution passed by the German Bundestag.

Supported by:

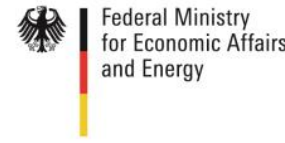

on the basis of a decision by the German Bundestag

\section{REFERENCES}

[1] Klement, W., Willens, R. H.\& Duwez, P. 1960: Non-crystalline Structur in Solidified Gold-Silicon Alloys, Nature, 187 (4740), $869-870$.

[2] Schroers, J. 2010: Processing of bulk metallic glass, Advanced materials, 22 (14), pp. 1566-1597.

[3] Inoue, A., Shen, B., Koshiba, H., Kato, H.\& Yavari, A. R. 2003: Cobalt-based bulk glassy alloy with ultra high strength and soft magnetic properties, 2 (10), pp. 661-663.

[4] Busch, R., Schroers, J.\& Wang, W. H. 2007: Thermodynamics and Kinetics of Bulk Metallic Glass, MRS Bulletin, 32 (8), pp. 620-623.

[5] Scipioni Bertoli, U., Guss, G., Wu, S., Matthews, M. J.\& Schoenung, J. M. 2017: In-situ characterization of laser-powder interaction and cooling rates through high-speed imaging of powder bed fusion additive manufacturing, Materials \& Design, 135, pp. 385-396.

[6] Johan Lindwall: Modelling of Bulk Metallic Glass formation in Powder Bed Fusion.

[7] Pauly, S., Löber, L., Petters, R., Stoica, M., Scudino, S., Kühn, U.\& Eckert, J. 2013: Processing metallic glasses by selective laser melting, Materials Today, 16 ((1-2, pp. 37-41.

[8] Jung, H. Y., Choi, S. J., Prashanth, K. G., Stoica, M., Scudino, S., Yi, S., Kühn, U., Kim, D. H., Kim, K. B.\& Eckert, J. 2015: Fabrication of Fe-based bulk metallic glass by selective laser melting: A parameter study, Materials \& Design, 86, pp. 703-708.

[9] Ouyang, Di, Li, N., Xing, W., Zhang, J.\& Liu, L. 2017: 3D printing of crack-free high strength Zr-based bulk metallic glass composite by selective laser melting, Intermetallics, 90, pp. 128-134.

[10] Li, X. P., Kang, C. W., Huang, H., Zhang, L. C.\& Sercombe, T. B. 2014: Selective laser melting of an Al86Ni6Y4.5Co2La1.5 metallic glass: Processing, microstructure evolution and mechanical properties, Materials Science and Engineering: A, 606, pp. 370-379.

[11] Pauly, S., Schricker, C., Scudino, S., Deng, L.\& Kühn, U. 2017: Processing a glass-forming Zr-based alloy by selective laser melting, Materials \& Design, 135, pp. 133-141. 
[12] Li, X. P., Roberts, M. P., O’Keeffe, S.\& Sercombe, T. B. 2016: Selective laser melting of Zr-based bulk metallic glasses: Processing, microstructure and mechanical properties, Materials \& Design, 112, pp. 217 226.

[13] Karg, M. C. H., Ahuja, B., Hentschel, O.\& Schmidt, M. 2015: Local Hardness Variation of Ti50Cu32Ni15Sn3 Processed by Laser Beam Melting (LBM), International Journal of Recent Contributions from Engineering, Science \& IT (iJES), 3 (((1), pp. 34.

[14] Bordeenithikasem, P., Stolpe, M., Elsen, A.\& Hofmann, D. C. 2018: Glass forming ability, flexural strength, and wear properties of additively manufactured $\mathrm{Zr}$-based bulk metallic glasses produced through laser powder bed fusion, Additive Manufacturing, 21, pp. 312-317.

[15] Mahbooba, Z., Thorsson, L., Unosson, M., Skoglund, P., West, H., Horn, T., Rock, C., Vogli, E.\& Harrysson, 0. 2018: Additive manufacturing of an iron-based bulk metallic glass larger than the critical casting thickness, Applied Materials Today, 11, pp. 264-269.

[16] O'Neal B., 2019: Heraeus Creates Largest 3D Printed Gear Wheel Made from Amorphous Metals (https://3dprint.com/240614/heraeus-creates-largest-3d-printed-gear-wheel-made-amorphous-metals/).

[17] Bordeenithikasem, P., Shen, Y., Tsai, H.-L.\& Hofmann, D. C. 2018: Enhanced mechanical properties of additively manufactured bulk metallic glasses produced through laser foil printing from continuous sheetmetal feedstock, Additive Manufacturing, 19, pp. 95-103.

[18] Sarac, B.\& Schroers, J. 2013: From brittle to ductile: Density optimization for Zr-BMG cellular structures, Scripta Materialia, 68 (12), pp. 921-924.

[19] Qu, R. T., Zhao, J. X., Stoica, M., Eckert, J.\& Zhang, Z. F. 2012: Macroscopic tensile plasticity of bulk metallic glass through designed artificial defects, Materials Science and Engineering: A, 534, pp. 365-373.

[20] Sarac, B.\& Schroers, J. 2013: Designing tensile ductility in metallic glasses, Nature communications, 4, pp. 2158.

[21] King, W. E., Anderson, A. T., Ferencz, R. M., Hodge, N. E., Kamath, C., Khairallah, S. A.\& Rubenchik, A. M. 2015: Laser powder bed fusion additive manufacturing of metals; physics, computational, and materials challenges, Applied Physics Reviews, 2 (4), pp. 41304.

[22] Yang, C., Zhang, C., Xing, W.\& Liu, L. 2018: 3D printing of Zr-based bulk metallic glasses with complex geometries and enhanced catalytic properties, Intermetallics, 94, pp. 22-28.

[23] Homer, E. R., Harris, M. B., Zirbel, S. A., Kolodziejska, J. A., Kozachkov, H., Trease, B. P., Borgonia, J.-P. C., Agnes, G. S., Howell, L. L.\& Hofmann, D. C. 2014: New Methods for Developing and Manufacturing Compliant Mechanisms Utilizing Bulk Metallic Glass, Advanced Engineering Materials, 16 (7), pp. 850-856.

[24] Li, X. 2017: Additive Manufacturing of Advanced Multi-Component Alloys: Bulk Metallic Glasses and High Entropy Alloys, Advanced Engineering Materials, 11, pp. 1700874.

[25] Heraeus Additive Manufacturing GmbH, 2018: Metal Powder AMZ4 Data sheet.

[26] Busch, R. 2000: The Thermophysical Properties of Bulk Metallic Glass-Forming Liquids, JOM, 52 (7), pp. 39-42.

[27] Wegner, J., Kleszczynski, S., Hechler, S., Witt, G.\& Busch, R.: Parameter study about processing Zrbased bulk metallic glass with Laser beam melting, In: Witt, G. (Hrsg.): Rapid.Tech - International Trade Show \& Conference for Additive Manufacturing: Proceedings of the $15^{\text {th }}$ Rapid.Tech Conference, München, Carl Hanser Verlag GmbH \& Co. KG, 2017.

[28] Heinrich, J., Busch, R.\& Nonnenmacher, B. 2012: Processing of a bulk metallic glass forming alloy based on industrial grade $\mathrm{Zr}$, Intermetallics, 25, pp. 1-4. 